The efficacy of those seed treatments which were found to give a good measure of control of other seedborne diseases of flax in Northern Ireland ${ }^{3}$ was accordingly tested. The effectiveness of each treatment was determined in the laboratory by the modified Ulster method, five hundred seeds being examined in each case. Treatment with 'Nomersan' at the rate of $12 \mathrm{oz}$. per cwt. of seed or with 'Ceresan U564', using an 8 per cent solution at the rate of 0.9 gal. per cwt. of seed, reduced the contamination of the seed with viable $B$. cinerea from $15 \cdot 0$ per cent in the control to 0.4 and 1.4 per cent respectively in 1942 and from $13 \cdot 1$ per cent (control) to $1 \cdot 2$ and $1 \cdot 6$ per cent respectively in 1943 . Organo mercurial powders applied by the 'fixation' method of seed treatment were not so effective.

In pot experiments made both in the greenhouse and under an open outdoor verandah very satisfactory control of the disease was obtained by the use of both 'Nomersan' and 'Ceresan U564'. In field. tests 'Ceresan U564' was very effective, 'Nomersan' also giving good results. Unfortunately, in the field trials made in 1942 the development of the disease was almost completely checked at a very early stage by the onset of cold dry weather, and the yield of fibre was not influenced by treatment. In a similar field trial in 1943 the disease did not appear even in the control plots, probably due to the cold weather which followed sowing.

Observations made in the field show that $B$. cinerea can attack and kill portions of stems of mature plants, and that it is often present on the stems and capsules of plants if prolonged periods of damp weather occur after the crop has been pulled.

Ministry of Agriculture, N.I. JoHN COLHOUN.

Plant Disease Division,

The Queen's University, Belfast.

Nov. 29.

1 Muskett, A. E., and Malone, J. P., Ann. Appl. Biol., 28, 8 (1941).

${ }^{2}$ Van Poeteren, H.. Versl. en Meded. Plantenziektenkundigen Dienst te Wageningen, 44, 60 (1926).

${ }^{3}$ Muskett, A. E., and Colhoun, J., Ann. Appl. Biol., 30, 7 (1943).

'Muskett, A. E., and Colhoun, J., Ann. Bot., N.S. 6, 219 (1942).

\section{Future of Anthropology}

Prof. Le Gros Clark ${ }^{1}$ takes exception to remarks which I made in reporting a discussion on the future of anthropology at the recent centenary meeting of the Royal Anthropological Institute. The point at issue concerns the scope of physical anthropology. It would be generally agreed, no doubt, that this is a practical question concerning the convenience of study rather than an attempt to frame a logical definition of a subdivision of science.

Prof. Le Gros Clark refers to his presidential address to Section $\mathrm{H}$ of the British Association in 1939. In this he adopts the commonly held view that physical anthropology is concerned with the evolutionary history of man. This is a historical theme though it embraces the study of existing populations. Contact is made with the activities of students who are concerned with living peoples but who have no special interest in any historical theme. It is clear that research in this field cannot be divided into a number of separated compartments. It should all be related and interdependent, however various the approaches may be.

In the communication referred to, the physical anthropologist is urged to study "comparative racial physiology". His subject, we are told, should be completely re-orientated "along functional lines", its main concern (the italics are mine) being the study of physical efficiency in "native populations", with reference to all factors which influence it-such as inborn differences, nutrition and other environmental conditions-and all other relevant kinds of evidence, including medical and demographic statistics and the application of various physiological and other tests. But why restrict the scope of such inquiries to native populations, since anthropology is concerned with the whole of mankind? Are its students also expected to carry out research on the same lines for all "advanced" populations as well ?

It is clear that research of the kind referred to is needed, and that its results would be of interest to physical anthropologists. The question is whether they can be expected to consider that problems of the kind referred to should be their special concern. If they do, then the diversion of their very limited resources-at present almost non-existent in Great Britain-must entail neglect of 'academic' physical anthropology. Alternatively, it may be supposed that researches into the social biology of any kind of society can be more properly considered the concern of other workers, whether they be called social biologists, or eugenists, or something else. They might well urge that investigation of the questions involved, which are of immediate practical importance, should be undertaken by the State and not left to university workers.

Prof. Le Gros Clark exclaims at the suggestion, which he incorrectly attributes to me, that physical anthropologists cease to be such if they deal with practical problems. I should say that in so far as they do so, they are serving the 'applied' rather than the 'pure' interests of their science. Zoologists are not expected to be specialists in animal husbandry. The Writer of the Article.

${ }^{1}$ NATURE, 152, 689 (1943).

\section{Mathematics as a Cultural Subject}

THe plea in the editorial in NaTuRE of November 13 on "Science as an Educational Discipline" will find a warm welcome from those who have been concerned with spreading an understanding of the broad significance of science for modern society as well as the details of particular parts of science. Paying less attention to sharp division of science into different subjects and more to the interrelation of these subjects, the history and development of our great heritage and the social possibilities which it holds forth will help to spread a better appreciation of what science stands for among the population at large.

Here I would like to urge that mathematics should also be treated from the same point of view, and should not be put on one side as though it were totally different. The conventional approach to the subject only too often seems to make it appear mysterious, esoteric and external to the pupil's experiences. Without a clear understanding of what mathematics can do and what it cannot do, then it is very easy to be misled by all kinds of arguments using quite unjustifiable mathematical proofs. If mathematics is linked up more elosely with the physical sciences, then it is possible to explain the significance of such developments as the calculus and graphs, and to 